\title{
The Effectiveness of Online Learning Through Undiksha E- Learning During the Covid-19 Pandemic
}

\author{
I Made Satyawan ${ }^{*}$, Wahjoedi ${ }^{2}$, I Ketut Iwan Swadesi ${ }^{3}$ (D) \\ 1,2,3 Universitas Pendidikan Ganesha, Singaraja, Indonesia \\ e-mail: made.satyawan@undiksha.ac.id,wahjoedi@undiksha.ac.id,iwan.swadesi@undiksha.ac.id
}

\section{A R T I C L E I N F O}

Article history:

Received February 27, 2021

Revised April 22, 2021

Accepted May 03, 2021

Available online May 25, 2021

Kata Kunci:

E-Learning, Pembelajaran

Daring, Pandemi Covid-19

Keywords:

E-Learning, Online Learning,

Covid-19 Pandemic

\begin{abstract}
A B S T R A K
Keefektifan e-learning undiksha sebagai salah satu media pembelajaran resmi prodi penjaskesrek undiksha belum terukur secara ilmiah. Penelitian ini bertujuan untuk mengetahui gambaran efektivitas pembelajaran daring menggunakan E-Learning Undiksha pada program studi penjaskesrek selama pandemi covid-19. Penelitian ini merupakan penelitian kuantitatif deskriptif dengan desain survey. Sampel penelitian ini adalah seluruh mahasiswa program studi penjaskesrek yang berjumlah 120 orang. Instrumen pengumpulan data menggunakan angket yang dikemas menjadi google forms. Analisis data menggunakan statistik deskriptif. Hasil penelitian menunjukkan bahwa bahwa pembelajaran daring menggunakan E-Learning Undiksha selama pandemi covid-19 pada program studi penjaskesrek tergolong efektif. Hal ini terungkap dari pembelajaran secara daring dengan menggunakan E-Learning Undiksha konsentrasi mahasiswa dalam memperhatikan penjelasan dari dosen sebesar 96\%, tingkat pemahaman mahasiswa terhadap materi pembelajaran 88\%, motivasi mahasiswa dalam mengikuti pembelajaran daring dengan menggunakan E-Learning Undiksha sebesar 77\%, dan pada hasil belajar mahasiswa tergolong sebesar $88 \%$. Hasil penelitian menunjukan bahwa Pembelajaran daring menggunakan E-Learning Undiksha selama pandemi covid-19 pada program studi penjaskesrek tergolong efektif. Hasil penelitian ini berimplikasi pada keberlanjutan penggunaan e-learning undiksha sebagai salah satu platform pembelajaran yang digunakan oleh dosen dan mahasiswa Undiksha.
\end{abstract}

\section{A B S T R A C T}

The effectiveness of Undiksha e-learning as one of the official learning media for the Undiksha Physical and Health Study Program has not been measured scientifically. This study aims to describe the effectiveness of online learning using Undiksha E-Learning in the Physical Education and Health Study program during the COVID-19 pandemic. This research is descriptive quantitative research with a survey design. The sample of this study was all students of the Physical Education Study Program, amounting to 120 people. The data collection instrument uses a questionnaire packaged into google forms. Data analysis used descriptive statistics. The results showed that online learning using Undiksha's E-Learning during the covid-19 pandemic in the Physical Education and Health Study program was quite effective. This is revealed from online learning using Undiksha E-Learning, the concentration of students in paying attention to the explanations of the lecturers is $96 \%$, the level of student understanding of learning materials is $88 \%$, student motivation in participating in online learning using Undiksha E-Learning is $77 \%$, and on student learning outcomes classified as $88 \%$. The results of the study show that online learning using Undiksha's E-Learning during the covid-19 pandemic in the Physical Education and Health Study program is quite effective. The results of this study have implications for the sustainability of the use of Undiksha e-learning as a learning platform used by Undiksha lecturers and students.

This is an open access article under the $\underline{C C B Y-S A}$ license.

Copyright (C) 2021 by Author. Published by Universitas Pendidikan Ganesha

\section{INTRODUCTION}

The world's education system is currently being disrupted by the Covid-19 outbreak. Covid-19 is a disease whose cause is identified as the Coronavirus that attacks the respiratory tract. This disease was first detected in Wuhan, China (Calvo et al., 2020; Olonade, Adetunde, Iwelumor, Ozoya, \& George, 2021; Wen et al., 2020). On January 30, 2020, the World Health Organization (WHO) declared the COVID-19 outbreak a state of emergency, a global pandemic, and required the whole world to immediately make efforts to stop and contain the spread of COVID-19 (Djalante et al., 2020; Herliandry, Enjelina, \& Kuswanto, 2020; Sohrabi et al., 2020). Since its spread to Indonesia, the Indonesian government has tried to suppress the spread of Covid-19 by carrying out physical restrictions or physical distancing. This has an impact on various aspects of social, economic, cultural, and even educational life. The Indonesian Ministry of Education issued a Circular Letter of 
the Minister of Education and Culture No. 4 of 2020 concerning the Implementation of Policies and Education in an Emergency Period for the Spread of Corona Virus Disease (Covid-19) by replacing the learning process in schools and universities by using an online system and implementing a Work From Policy policy Home (WFH) (Dewi, 2020; Maulana \& Hamidi, 2020; Robandi \& Mudjiran, 2020). Based on the circular, the learning system at Undiksha changed drastically from face-to-face/offline meetings to online/network learning. Undiksha itself carries out online learning using the Undiksha E-Learning platform which has been independently developed by Undiksha. This applies to all study programs at Undiksha, including the Physical Education Study Program, where $70 \%$ of the learning is carried out by means of practicum. In this pandemic situation, learning with Undiksha E-Learning is a solution to carry out the most effective and efficient learning.

The use of Undiksha E-Learning has been going on for 10 months since the official implementation of online learning in March 2020 at Undiksha. During this period, Undiksha E-Learning was the only official Undiksha Platform to carry out online learning. To use Undiksha's E-Learning on an ongoing basis, it is necessary to conduct evaluations and research related to the effectiveness of online learning with the Undiksha E-learning platform. This departs from several facts in the field which show that online learning does not necessarily provide good effectiveness in learning. The facts related to the use of various other types of online platforms at various universities in Indonesia show mixed results. The implementation of learning using elearning can significantly improve student learning outcomes (Diantari et al, 2018; Khusniyah, 2020; Kurtz, Tsimerman, \& Steiner, 2014). The implementation of learning through e-learning was quite effective for students (Ardini, Iswara, \& Retnani, 2020; Irawan, 2018). Mustakim (2020) in his research shows that the results of the study describe students assessing mathematics learning using online media as very effective (23.3\%). Although there are also students who consider online learning to be ineffective (10\%), and absolutely none $(0 \%)$ who consider it very ineffective. Dewantara \& Nurgiansah (2020) in their research showing that $79 \%$ of students want face-to-face learning, while only $21 \%$ of students want online learning, so it can be concluded that online learning is continuous throughout the period. this pandemic is very ineffective.

Moving on from the facts above, it can be concluded that online learning has various perceptions and results. Along with this, on the other hand, the Undiksha Penjaskesrek study program as one of the study programs that mostly carries out physical practicum learning is something that must be done to evaluate the implementation of online learning using the Undiksha e-learning platform. Given that before the Covid-19 pandemic, learning was mostly carried out outside the classroom or in the field. After the pandemic, the implementation of learning carried out in the Undiksha Physical Education and Health study program turned into online learning that cannot be carried out haphazardly outside the room without complying with the health protocols set by the government. This causes learning that requires practical activities such as running, jumping, throwing, catching, and so on cannot be carried out freely. In addition, by implementing online learning, students cannot witness directly the tutors who should be used as examples to practice effectively (Sayıner \& Ergönül, 2021; Shetu et al., 2021; Upadhyay \& Wadkin, 2021). Based on this, it is deemed necessary to conduct research related to the use of the Undiksha e-learning platform during the Covid-19 pandemic in the physical education program. This is an effort to evaluate the implementation of learning to determine decisions for implementing learning in the future.

Based on the explanation above, this study aims to determine the effectiveness of online learning through Undiksha's E-Learning during the Covid-19 pandemic in the Penjaskesrek Study Program. In addition, this study aims to produce material for consideration of the use of e-learning Undiksha in the Physical Education Study Program. The results of this study have implications for the sustainability of the use of Undiksha elearning in general as a learning platform used by Undiksha lecturers and students. The results of this study can be used as an evaluation material for the use of e-learning Undiksha. In addition, the results of this study can also be used as a consideration for improving the quality of e-learning Undiksha in the future.

\section{METHOD}

This study uses a quantitative descriptive research approach with a survey research design. The subjects of this study were all students of the Physical and Health Study program, totaling 120 people. This research was conducted in several stages, namely (1) developing a questionnaire instrument for the implementation of online learning with Undiksha E-Learning, (2) testing content validity, construct validity, and instrument reliability, (3) converting questionnaire items into Google Form, (4) Determine the research subject, (5) Distribute the instrument in the form of a Google Form link to the research subject through the study program's official social media and class whatsapp group, (6) Data analysis.

Data collection in this study used an online learning questionnaire instrument using Undiksha ELearning. The questionnaire used consists of four indicators, namely (1) student concentration in online learning with Undiksha E-Learning, (2) student understanding of learning materials (3) student motivation in online learning, (4) student learning outcomes in online learning. The four indicators are described into 20 questions 
consisting of favorable questions and unfavorable questions. The questionnaire for the implementation of online learning using Undiksha E-Learning can be seen in table 1.

Table 1. Online Learning Using Undiksha E-Learning Questionnaire Grid

\begin{tabular}{|c|c|c|c|c|}
\hline \multirow{2}{*}{ Variabel } & \multirow{2}{*}{ Indikator } & \multicolumn{2}{|c|}{ Items } & \multirow{2}{*}{ Total } \\
\hline & & Favorable & Unfavorable & \\
\hline \multirow{4}{*}{$\begin{array}{l}\text { Online learning } \\
\text { using Undiksha } \\
\text { E-Learning }\end{array}$} & $\begin{array}{l}\text { Student concentration in online learning } \\
\text { with Undiksha's E-Learning }\end{array}$ & $1,3,5$ & 2,4 & 5 \\
\hline & $\begin{array}{l}\text { Students' understanding of learning } \\
\text { materials }\end{array}$ & $6,8,10$ & 7,9 & 5 \\
\hline & Student motivation in online learning & 12,14 & $11,13,15$ & 5 \\
\hline & $\begin{array}{l}\text { Student learning outcomes in online } \\
\text { learning }\end{array}$ & $16,18,20$ & 17,19 & 5 \\
\hline
\end{tabular}

Before being used in the research, the content validity, construct validity, and reliability tests were carried out. The results of the validity test were carried out using the inter-rater aggrement technique of 2 learning media experts. The results of the content validity test show a score of 1 which means that the questionnaire on the implementation of online learning using Undiksha's E-Learning has very high content validity. Construct validity is done by testing the product moment validity. The results of the product moment validity test show that all questions have a calculated $r$ value above 0.444 in the questionnaire with $r$ table $\mathrm{N}=20$ at a significance of 5\%. While the results of the reliability test with Croanbach's alpha got a result of 0.933 , which means that the online learning implementation questionnaire using Undiksha E-Learning has very high reliability. The data analysis used is descriptive statistics to describe the data or determine the central tendency which includes the calculation of the average or mean (M), standard deviation (SD), mode (Mo) and median (Me), frequency and histogram of the variables studied. Data analysis in this study was carried out with the help of SPSS 26.0 For Windows.

\section{RESULT AND DISCUSSION}

Based on Figure 1, it can be seen that all lecturers of the Physical Education study program use Undiksha E-Learning during online learning during the covid 19 pandemic. This can be seen from the data which shows that $100 \%$ of the Physical Education and Health Study program lecturers use Undiksha E-Learning as a learning medium.

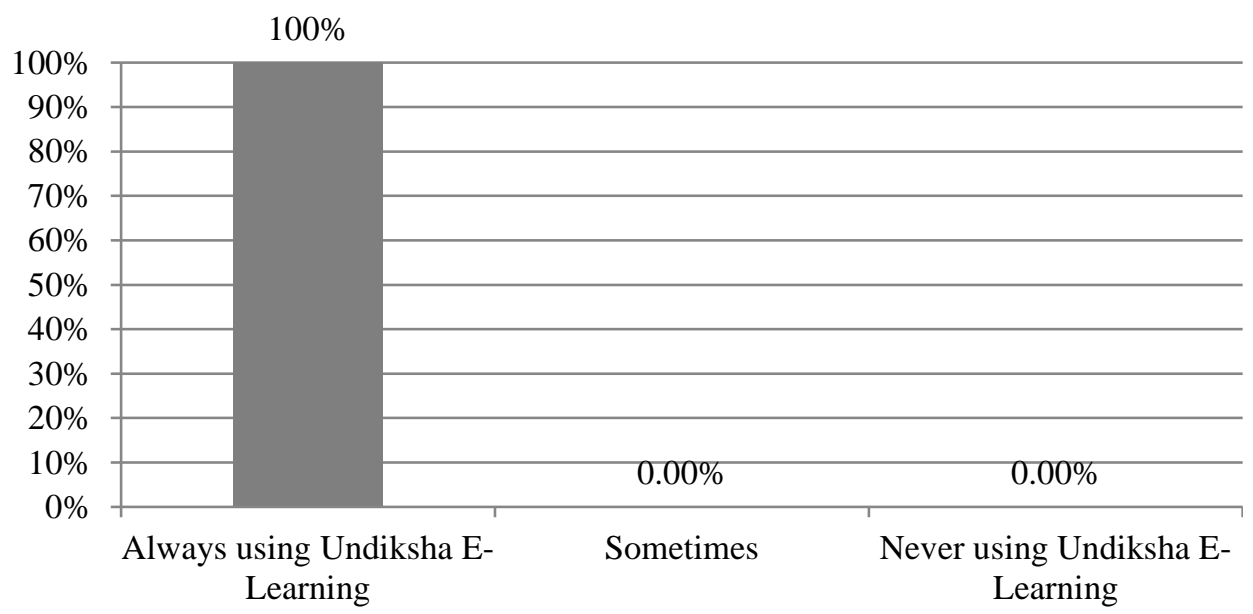

Figure 1. Percentage of Undiksha E-Learning Use by Lecturers of Physical Education Study Program

Regarding the concentration of students in online learning with Undiksha E-Learning, the results of the analysis show, from 120 students, $96 \%$ of students have very high concentration during the learning process, 
have a high concentration of $1.67 \%$, have a moderate concentration of $2,50 \%$, and $0 \%$ respectively in the category with low and very low concentrations. The details of the data can be visualized through Figure 2.

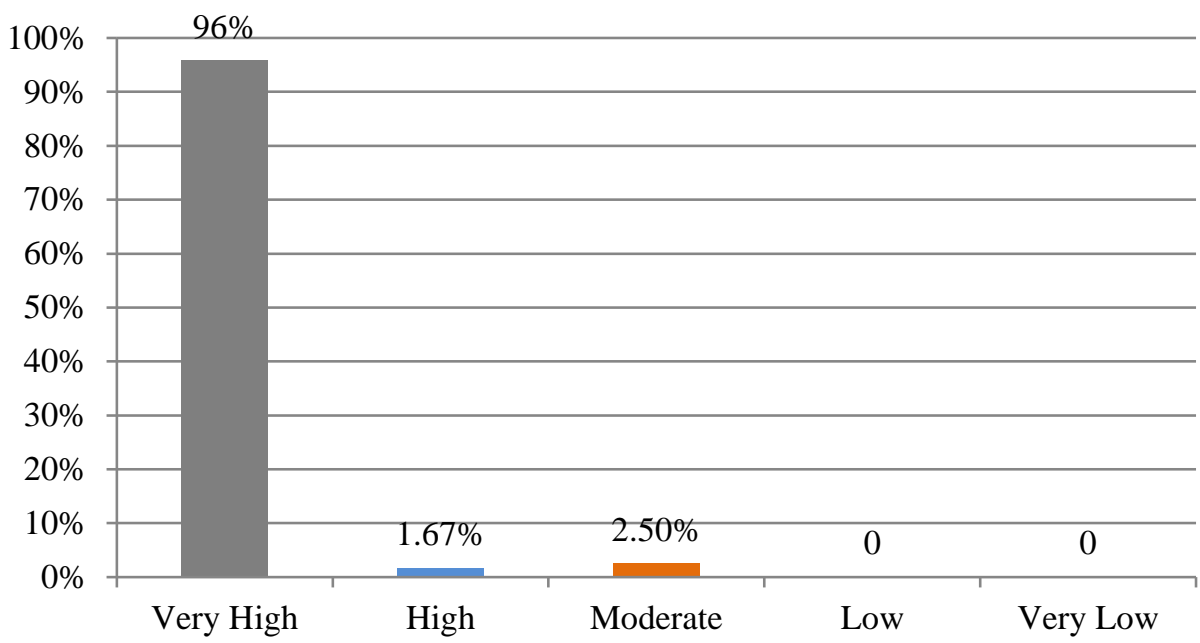

Figure 2. Student Concentration in online learning with Undiksha's E-Learning

Based on the results of the analysis carried out related to students' understanding of learning materials carried out using Undiksha E-Learning media, $88 \%$ of students have a very high understanding of learning materials, have an understanding of $9.16 \%$, have sufficient understanding of $3.34 \%$, and by $0 \%$ respectively who have low and very low understanding. In detail, the data can be visualized through Figure 3.

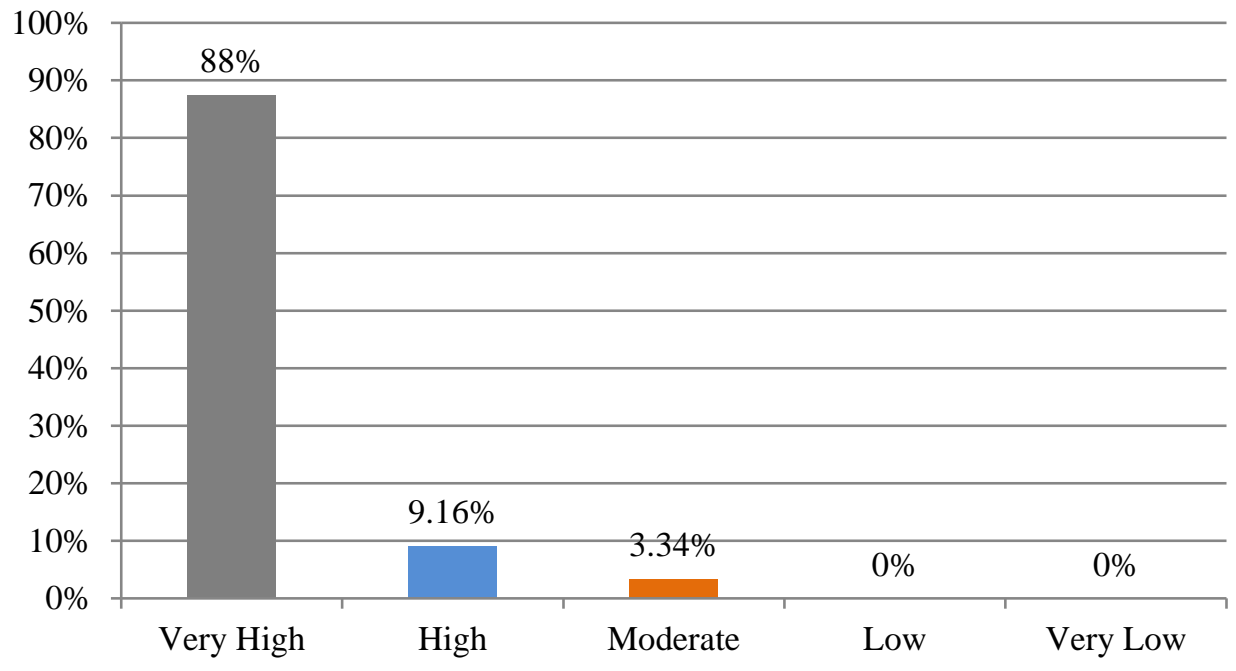

Figure 3. Students' understanding of learning materials

The results of data analysis related to student motivation in the learning process with Undiksha ELearning show that $77 \%$ of students have very high motivation, $1.67 \%$ of students have high motivation, $2.5 \%$ of students have moderate motivation, $19.17 \%$ of students have low motivation to learn, and $0 \%$ of students who are not motivated at all or have very low motivation. In detail the data can be seen in Figure 4. 


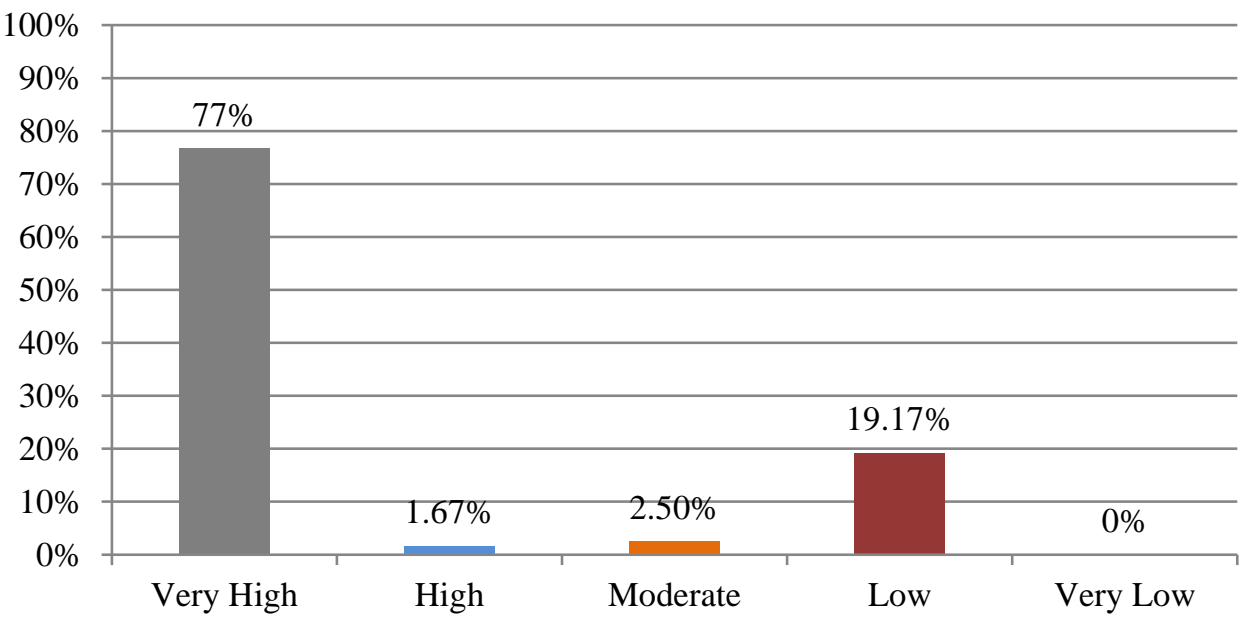

Figure 4. Student Motivation in Online Learning

Related to the learning outcomes obtained by students during online learning with Undiksha ELearning, $84 \%$ of student learning outcomes are classified as very high, in the high category by $15.83 \%$, in the moderate category by $1.67 \%$, low by $3.33 \%$, and in the very very low category of $3.33 \%$. In detail, the learning outcomes data can be visualized through Figure 05.

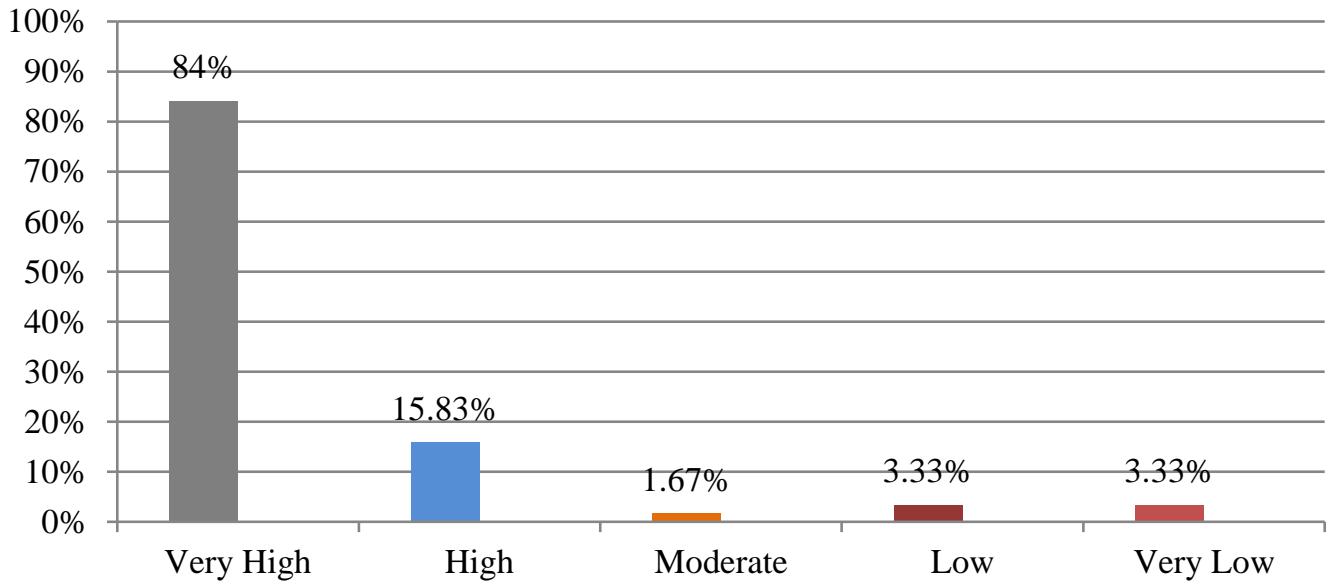

Figure 5. Student Learning Outcomes in Online Learning

Based on the results of data analysis, online learning using the Undiksha e-learning carried out by lecturers of the Physical Education Study Program during the COVID-19 pandemic is considered effective. It is revealed from Figures 2 to 5 that when learning takes place online using Undiksha E-Learning, the concentration of students is very high in the learning process, which is $96 \%$. While $88 \%$ of students have a very high level of understanding of the learning material. Furthermore, the motivation of students in participating in online learning is also very high at $77 \%$. The high level of concentration, understanding, and motivation of students towards online learning with Undiksha E-Learning leads to very high student learning outcomes. In accordance with the results of data analysis, of the 120 students who were the research subjects, $84 \%$ of students had very high learning outcomes. Based on all these data, it can be concluded that the use of Undiksha E-Learning as a learning medium during the covid-19 pandemic in the Physical Education and Health Study program is quite effective.

Online learning is not a new thing in the implementation of education in Indonesia. Several educational institutions have conducted online learning to support the implementation of offline learning. However, in recent times, online learning has been carried out in full at all levels and educational institutions in Indonesia (Anugrahana, 2020; Fitriyani, Fauzi, \& Sari, 2020; Handarini, Oktafia \& Wulandari, 2020). This is none other than the COVID-19 pandemic which requires every activity to implement a health protocol (Fitriyani et al., 
2020; Handarini, Oktafia \& Wulandari, 2020). E-learning is an abbreviation of electronic learning, which is a learning process that uses electronic media, especially the internet as a learning system (Baber, 2021; Nácher, Badenes-Ribera, Torrijos, Ballesteros, \& Cebadera, 2021; Shodiq \& Zainiyati, 2020). E-learning can be defined as learning that occurs when internet technology is used to facilitate, deliver, and enable distance learning processes (Logan, Johnson, \& Worsham, 2021; Mitra et al., 2021). In line with the definition of e-learning above, undiksha e-learning is an electronic learning media developed to support virtual distance learning. Undiksha e-learning.

The existence of e-learning media developed by Undiksha makes it easy for Undiksha students and lecturers to carry out learning, especially during the current covid 19 pandemic. The use of undiksha e-learning allows students and lecturers to carry out learning in their respective places without meeting in class. However, a situation like this can affect the learning process that is carried out, especially in the Physical and Health Study Program, where almost $75 \%$ of the courses are conducted with practical learning which is ideally carried out offline. This affects the concentration, motivation, understanding, and student learning outcomes of the learning carried out. The results of this study indicate that students have a high concentration in participating in learning using undiksha e-learning. This can be seen from the percentage of students who have a very high concentration of $96 \%$. The concentration of students in carrying out learning can be shaped by environmental factors and interesting learning media (Daniel \& Kamioka, 2017; Erwiza, Kartiko, \& Gimin, 2019). Learning carried out online provides opportunities for students to choose and determine a comfortable and conducive learning place according to student needs. Unlike the case when learning is carried out offline in the classroom, students will find it very difficult to concentrate because of the many objects of view that can distract students' concentration. In addition, learning with undiksha e-learning is something that is still considered new by most students, so that learning through undiksha e-learning is able to attract students' attention to focus on the learning process carried out.

On indicators of student understanding of learning materials, the results of the study showed that $88 \%$ of students had very high understanding of learning materials. The learning material in the Physical Education Study Program is not only in the form of theoretical material but also practice. Understanding the material will be comprehensive when students are able to understand theory and practice. In online learning through undiksha e-learning, students study separately from one student to another, as well as during practice. Psychologically, this kind of practice can provide psychological support to students. This is because students do not need to be awkward to do practical movements in accordance with the theory that has been studied. In contrast to the practice during offline learning, students tend to be psychologically depressed because they are observed directly by the lecturers and also all class students. Individuals tend to feel anxious when observed by other individuals (Ashdown-Franks, Sabiston, Solomon-Krakus, \& O'Loughlin, 2017; Mehrsafar, Moghadam Zadeh, Jaenes Sánchez, \& Gazerani, 2021). This applies to every individual, even though they have good abilities in certain sports practice areas (Ashdown-Franks et al., 2017; Kristjánsdóttir, Erlingsdóttir, \& Saavedra, 2018; Mehrsafar et al., 2021; Savage, Davey, Fullana, \& Harrison, 2020).

On indicators of student motivation in online learning, the results showed that $77 \%$ of students had very high motivation in online learning using e-learning Undiksha. Some of the principles of learning motivation include (1) Learners will be interested in learning if the topics studied are interesting and useful for themselves, (2) learning outcomes are always informed as soon as possible to students, (3) Learning objectives are clearly arranged and informed to students so that students have an understanding of the learning that is carried out (Brandmiller, Dumont, \& Becker, 2020; Huang, Kuo, \& Chen, 2020; Moll-Khosrawi, Cronje, Zöllner, Kubitz, \& Schulte-Uentrop, 2021). This principle is in line with the situation of the learning process using e-learning Undiksha where in e-learning Undiksha allows learning to be interesting because of the simple appearance of elearning and easy access to the use of e-learning Undiksha. In addition, in the Undiksha e-learning, it is possible to include planning tools and learning designs that allow students to know the objectives of the learning carried out. Regarding learning outcomes, Undiksha e-learning has several features that can be used as a medium for providing feedback according to the agreed time. Some of the features in this Undiksha e-learning can effectively increase student learning motivation

The results of this study indicate that learning using e-learning Undiksha is able to improve concentration, understanding, and student motivation in the very high category. The existence of concentration, understanding, and high motivation towards learning that is held directly has an impact on high learning outcomes. Concentration, understanding, and motivation in learning are very important internal factors in an effort to improve learning outcomes (Alhefnawi, 2021; Van Alten, Phielix, Janssen, \& Kester, 2019, 2020). This is in line with the results of this study which showed that $84 \%$ of students of the Physical Education Study Program had learning outcomes that were included in the very high category. The results of this study are in line with the results of research conducted by Fatmawati (2019) which found that discussion forums in learning conducted through Moodle-based e-learning were able to increase student learning participation when compared to discussions that occurred in conventional or classical classes face-to-face with an increase value of $37 \%$. E- 
learning was effective in the midst of the covid-19 pandemic (Ali et all 2021; Saeed \& Hammood, 2021; Shaik Alavudeen et al., 2021). This is indicated by the problem-solving ability of students meeting the minimum completeness criteria and student responses to learning in the positive category. Khusniyah (2020) found that learning using e-learning media has proven to be effective in increasing student understanding in social studies basic concepts, especially the social studies position material in the 2013 curriculum. It is proven by an increase in the average achievement of students' cognitive learning outcomes after learning. There are differences significant student cognitive learning outcomes between before and after using e-learning media

This research is a quantitative descriptive research, which means that the research is conducted only to describe the phenomena that occur in the field. This study did not provide intervention to research subjects to determine the effect of online learning using Undiksha E-Learning. The effect of the implementation of learning is known only based on the survey method which is analyzed into a conclusion. For future research, it is suggested to use an experimental design with independent variables of online learning using Undiksha ELearning. In this way, the effects of implementing online learning using Undiksha e-learning will be specifically known. The research design can be developed into a Time Series design to see the results and impacts of using the Undiksha e-learning platform in learning. The subject of this research is only limited to the Physical Education Study Program so that the results of the study cannot be generalized in general for the implementation of online learning with the Undiksha e-learning platform at Undiksha. Therefore, further similar research is recommended to conduct a survey with the subject of all study programs at Undiksha. In this way, the research results can represent the entire learning phenomenon that occurs in Undiksha.

\section{CONCLUSION}

Courageous learning to use Undiksha's E-Learning during the COVID-19 pandemic in the Physical Education and Health Study program is considered effective. The use of Undiksha E-learning can provide opportunities for students to choose a place that suits their needs to be able to concentrate on carrying out lectures. Individual practice can eliminate anxiety so that students are able to understand a comprehensive understanding of theory and practice. Undiksha e-learning has several features that are in accordance with the principle of increasing learning motivation. This increases student learning motivation using e-learning Undiksha as a learning medium. High student learning motivation has an impact on student learning outcomes. Therefore, Undiksha E-Learning as an official platform for bold learning is highly recommended to be used continuously in learning for all Undiksha students. Through this, it is recommended for all policy makers in Undiksha to require policies and students to carry out learning using the Undiksha e-learning platform.

\section{REFERENCES}

Alhefnawi, M. A. M. (2021). Assessing the efficacy of online handouts and active lectures in learning outcomes at the engineering undergraduate level. Ain Shams Engineering Journal, (xxxx). https://doi.org/10.1016/j.asej.2021.02.012.

Ali, S., Hafeez, Y., Humayun, M., Jamail, N. S. M., \& Aqib, M. (2021). Enabling recommendation system architecture in virtualized environment for e-learning. Egyptian Informatics Journal. https://doi.org/10.1016/j.eij.2021.05.003.

Anugrahana, A. (2020). Hambatan, Solusi dan Harapan : Pembelajaran Daring Selama Masa Pandemi Covid-19 Oleh Guru Sekolah Dasar. Scholaria: Jurnal Pendidikan Dan Kebudayaan, 10(3), 282-289.

Ardini, L., Iswara, U. S., \& Retnani, E. D. (2020). Efektivitas Penggunaan E-Learning Sebagai Media Pembelajaran Saat Pandemi Covid 19. JKBM:Jurnal Konsep Bisnis Dan Manajemen, 7(1), 72-81. https://doi.org/10.31289/jkbm.v7i1.4333.

Ashdown-Franks, G., Sabiston, C. M., Solomon-Krakus, S., \& O’Loughlin, J. L. (2017). Sport participation in high school and anxiety symptoms in young adulthood. Mental Health and Physical Activity, 12, 19-24. https://doi.org/10.1016/j.mhpa.2016.12.001.

Baber, H. (2021). Modelling the acceptance of e-learning during the pandemic of COVID-19-A study of South Korea. The International Journal of Management Education, 19(2). https://doi.org/10.1016/j.ijme.2021.100503.

Brandmiller, C., Dumont, H., \& Becker, M. (2020). Teacher Perceptions of Learning Motivation and Classroom Behavior: The Role of Student Characteristics. Contemporary Educational Psychology, 63, 101893. https://doi.org/10.1016/j.cedpsych.2020.101893.

Calvo, C., López-hortelano, M. G., Carlos, J., Vicente, D. C., Luis, J., Martínez, V., ... Asociación, D. (2020). Recommendations on the clinical management of the COVID-19 infection by the (new coronavirus) 
SARS-CoV2. Clinical Management of Infection By, 92(4). https://doi.org/10.1016/j.anpede.2020.02.002

Daniel, K. N., \& Kamioka, E. (2017). Detection of Learner's Concentration in Distance Learning System with Multiple Biological Information. Journal of Computer and Communications, 05(04), 1-15. https://doi.org/10.4236/jcc.2017.54001.

Dewi, W. A. F. (2020). Dampak COVID-19 terhadap Implementasi Pembelajaran Daring di Sekolah Dasar. Edukatif: Jurnal Ilmu Pendidikan, 2(1), 55-61. https://doi.org/10.31004/edukatif.v2i1.89.

Diantari, Damayanthi, Sugihartini, \& Wirawan. (2018). Pengembangan E-modul berbasis Mastery Learning untuk Mata Pelajaran KKPI Kelas XI. Jurnal Nasional Pendidikan Teknik Informatika (Janapati), 7(1), 33-48. http://dx.doi.org/10.23887/janapati.v7i1.12166.

Djalante, R., Lassa, J., Setiamarga, D., Sudjatma, A., Indrawan, M., Haryanto, B., ... Warsilah, H. (2020). Review and analysis of current responses to COVID-19 in Indonesia: Period of January to March 2020. Progress in Disaster Science, 6, 100091. https://doi.org/10.1016/j.pdisas.2020.100091.

Erwiza, Kartiko, S., \& Gimin. (2019). Factors Affecting the Concentration of Learning and Critical Thinking on Student Learning Achievement in Economic Subject. Journal of Educational Sciences, 3(2), 205-215. https://doi.org/10.31258/jes.3.2.p.205-215.

Fatmawati, S. (2019). Efektivitas Forum Diskusi Pada E-Learning Berbasis Moodle Untuk Meningkatkan Partisipasi Belajar. Refleksi Edukatika: Jurnal Ilmiah Kependidikan, 9(2). https://doi.org/10.24176/re.v9i2.3379.

Fitriyani, Y., Fauzi, I., \& Sari, M. Z. (2020). Motivasi Belajar Mahasiswa Pada Pembelajaran Daring Selama Pandemik Covid-19. Profesi Pendidikan Dasar, 7(1), 121-132. https://doi.org/10.23917/ppd.v7i1.10973.

Handarini, Oktafia, I., \& Wulandari, S. S. (2020). Pembelajaran Daring Sebagai Upaya Study From Home (SFH) Selama Pandemi Covid-19. Jurnal Pendidikan Administrasi Perkantoran, 8(3). Retrieved from https://jurnal.unesa.ac.id/index.php/jpap/article/view/8503.

Herliandry, Enjelina, \& Kuswanto. (2020). Pembelajaran Pada Masa Pandemi Covid-19. Jurnal Teknologi Pendidikan, 22(1). Retrieved from https://doi.org/10.21009/jtp.v22i1.15286.

Huang, S. Y., Kuo, Y. H., \& Chen, H. C. (2020). Applying digital escape rooms infused with science teaching in elementary school: Learning performance, learning motivation, and problem-solving ability. Thinking Skills and Creativity, 37(129), 100681. https://doi.org/10.1016/j.tsc.2020.100681.

Irawan, H. (2018). Keefektifan E-Learning Sebagai Media Pembelajaran (Studi Evaluasi Model Pembelajaran ELearning Smk Telkom Sandhy Putra Purwokerto). Jurnal Inovasi Teknologi Pendidikan, 5(1), 1-11. https://doi.org/10.21831/jpv.v3i1.1584.

Khusniyah, T. W. (2020). Efektivitas E-Learning Terhadap Hasil Belajar. Susunan Artikel Pendidikan, 4(3), 207-214. http://dx.doi.org/10.30998/sap.v4i3.6283.

Kristjánsdóttir, H., Erlingsdóttir, A. V., \& Saavedra, J. M. (2018). Psychological skills, mental toughness and anxiety in elite handball players. Personality and Individual Differences, 134(June), 125-130. https://doi.org/10.1016/j.paid.2018.06.011.

Kurtz, G., Tsimerman, A., \& Steiner, O. (2014). The Flipped Classroom Answer to Future Learning? European Journal of Open, Distance and E-Learning, 17(2). https://doi.org/10.2478/eurodl-2014-0027.

Logan, R. M., Johnson, C. E., \& Worsham, J. W. (2021). Development of an E-learning Module to Facilitate Student Learning and Outcomes. Teaching and Learning in Nursing, 16(2), 139-142. https://doi.org/10.1016/j.teln.2020.10.007.

Maulana, H. A., \& Hamidi, M. (2020). Persepsi Mahasiswa terhadap Pembelajaran Daring pada Mata Kuliah Praktik di Pendidikan Vokasi. Equilibrium: Jurnal Pendidikan, 8(2), 224-231. https://doi.org/10.26618/equilibrium.v8i2.3443.

Mehrsafar, A. H., Moghadam Zadeh, A., Jaenes Sánchez, J. C., \& Gazerani, P. (2021). Competitive anxiety or Coronavirus anxiety? The psychophysiological responses of professional football players after returning to competition during the COVID-19 pandemic. Psychoneuroendocrinology, 129(January), 105269. https://doi.org/10.1016/j.psyneuen.2021.105269.

Mitra, N. K., Aung, H. H., Kumari, M., Perera, J., Sivakumar, A., Singh, A., \& Nadarajah, V. D. (2021). Improving the learning process in anatomy practical sessions of chiropractic program using e-learning tool. Translational Research in Anatomy, 23, 100100. https://doi.org/10.1016/j.tria.2020.100100.

Moll-Khosrawi, P., Cronje, J. S., Zöllner, C., Kubitz, J. C., \& Schulte-Uentrop, L. (2021). Understanding How the Motivational Dimension of Learning is Influenced by Clinical Teaching in Medical Education: A Prospective Cohort Study. Annals of Medicine and Surgery, 65(February), 1-7. https://doi.org/10.1016/j.amsu.2021.102366.

Mustakim, M. (2020). Efektivitas Pembelajaran Daring Menggunakan Media Online Selama Pandemi Covid-19 Pada Mata Pelajaran Matematika. Al Asma: Journal of Islamic Education, 2(1), 1-12. https://doi.org/10.24252/asma.v2i1.13646. 
Nácher, M. J., Badenes-Ribera, L., Torrijos, C., Ballesteros, M. A., \& Cebadera, E. (2021). The effectiveness of the GoKoan e-learning platform in improving university students' academic performance. Studies in Educational Evaluation, 70. https://doi.org/10.1016/j.stueduc.2021.101026.

Olonade, O. Y., Adetunde, C. O., Iwelumor, O. S., Ozoya, M. I., \& George, T. O. (2021). Heliyon Coronavirus pandemic and spirituality in southwest Nigeria: A sociological analysis. Heliyon, 7(March), e06451. https://doi.org/10.1016/j.heliyon.2021.e06451.

Robandi, D., \& Mudjiran, M. (2020). Dampak Pembelajaran Dari Masa Pandemi Covid-19 terhadap Motivasi Belajar Siswa SMP di Kota Bukittinggi. Jurnal Pendidikan Tambusai, 4(3), 3498-3502. https://doi.org/10.31004/jptam.v4i3.878.

Saeed, E. M. H., \& Hammood, B. A. (2021). Estimation and evaluation of Students' behaviors in E- learning Environment using adaptive computing. Proceedings. https://doi.org/10.1016/j.matpr.2021.04.519.

Savage, H. S., Davey, C. G., Fullana, M. A., \& Harrison, B. J. (2020). Threat and safety reversal learning in social anxiety disorder - an fMRI study. Journal of Anxiety Disorders, 76, 102321. https://doi.org/10.1016/j.janxdis.2020.102321.

Sayıner, A. A., \& Ergönül, E. (2021). E-learning in clinical microbiology and infectious diseases. Clinical Microbiology and Infection, 28. https://doi.org/10.1016/j.cmi.2021.05.010.

Shaik Alavudeen, S., Easwaran, V., Iqbal Mir, J., Shahrani, S. M., Ali Aseeri, A., Abdullah Khan, N., ... Abdullah Asiri, A. (2021). The influence of COVID-19 related psychological and demographic variables on the effectiveness of e-learning among health care students in the southern region of Saudi Arabia. Saudi Pharmaceutical Journal. https://doi.org/10.1016/j.jsps.2021.05.009.

Shetu, S. F., Rahman, M. M., Ahmed, A., Mahin, M. F., Akib, M. A. U., \& Saifuzzaman, M. (2021). Impactful e-learning framework: A new hybrid form of education. Current Research in Behavioral Sciences, 2(April), 100038. https://doi.org/10.1016/j.crbeha.2021.100038.

Shodiq, I. J., \& Zainiyati, H. S. (2020). Pemanfaatan Media Pembelajaran E-Learning Menggunakan Whastsapp Sebagai Solusi Ditengah Penyebaran Covid-19 Di Mi Nurulhuda Jelu. Al-Insyiroh: Jurnal Studi Keislaman, 6(2), 144-159. https://doi.org/10.35309/alinsyiroh.v6i2.3946.

Sohrabi, C., Alsafi, Z., O’Neill, N., Khan, M., Kerwan, A., Al-Jabir, A., ... Agha, R. (2020). World Health Organization declares global emergency: A review of the 2019 novel coronavirus (COVID-19). International Journal of Surgery, 76(February), 71-76. https://doi.org/10.1016/j.ijsu.2020.02.034.

Upadhyay, N., \& Wadkin, J. C. R. (2021). Can training in diagnostic radiology be moved online during the COVID-19 pandemic? UK trainee perceptions of the Radiology-Integrated Training Initiative (R-ITI) elearning platform. Clinical Radiology, 18 .

Van Alten, D. C. D., Phielix, C., Janssen, J., \& Kester, L. (2019). Effects of flipping the classroom on learning outcomes and satisfaction: A meta-analysis. Educational Research Review, 28(June), 1-18. https://doi.org/10.1016/j.edurev.2019.05.003.

Van Alten, D. C. D., Phielix, C., Janssen, J., \& Kester, L. (2020). Self-regulated learning support in flipped learning videos enhances learning outcomes. Computers and Education, 158(August), 104000. https://doi.org/10.1016/j.compedu.2020.104000.

Wen, J., Cheng, Y., Ling, R., Dai, Y., Huang, B., Huang, W., ... Jiang, Y. (2020). International Journal of Infectious Diseases Antibody-dependent enhancement of coronavirus. International Journal of Infectious Diseases, 100, 483-489. https://doi.org/10.1016/j.ijid.2020.09.015. 